\title{
THERMAL STABILITY OF SYNTHETIC PEPTIDES MIMICKING THE SEQUENCE OF THE REGION CONTAINING THE SKIP RESIDUES IN SQUID MYOSIN ROD
}

\author{
Yoshihiro Ochiai ${ }^{1}$, Mala Nurilmala ${ }^{2 \star}$, GuoFeng Wang ${ }^{3}$, Shugo Watabe ${ }^{4}$ \\ ${ }^{1}$ Graduate School of Agricultural Science, Tohoku University, Aramaki, Aoba, Sendai, \\ Miyagi 981-0845, Japan \\ ${ }^{2}$ Department of Aquatic Product Technology, Faculty of Fisheries and Marine Sciences, Bogor Agricultural \\ University, Indonesia \\ ${ }^{3}$ Formerly, Graduate School of Agricultural and Life Sciences, The University of Tokyo, Bunkyo, Tokyo \\ 113-8657, Japan \\ ${ }^{4}$ School of Marine Biosciences, Kitasato University, Sagamihara, Kanagawa 252-0373, Japan \\ ${ }^{*}$ Corresponding author: mnurilmala@ipb.ac.id \\ Diterima: 25 Januari 2017/ Disetujui: 07 April 2017
}

Citation: Ochiai Y, Nurilmala M, Wang GF, Watabe S. 2017. Thermal stability of synthetic peptides mimicking the sequence of the region containing the skip residues in squid myosin rod. Jurnal Pengolahan Hasil Perikanan Indonesia. 20(2): 319-328.

\begin{abstract}
Myosin is the major protein in skeletal muscles including those of fish and shellfish. The characteristics of this protein are closely related to the biological function and the quality and physical properties of muscle food. In the myosin rod (the coiled-coil region of myosin), several amino acid residues, known as skip residues, seem to destabilize the ordered structure (heptad repeat). These residues might be responsible for reducing thermal stability. Attempts were thus made to examine the role of these residues in the rod of squid myosin, based on the thermodynamic properties of synthetic peptides which have been designed to mimic the partial sequence of myosin heavy chain from the squid Todarodes pacificus mantle muscle. Five peptides, namely, with the sequence of $\operatorname{Trp}^{1343}-\mathrm{Ala}^{1372}$ having the skip residue $\mathrm{Glu}^{1357}$ at the center (Peptide WT), without the skip residue (Peptide $\Delta$ ), with the replacements of the skip residue (Glu) by Ile, Gln and Pro (Peptides E/I, E/Q, and E/P, respectively) to modify the helix forming propensity, were synthesized. The results obtained showed that the stability of the peptides as measured by circular dichroism spectrometry was in the order of Peptide $\Delta>$ Peptide WT $>$ Peptide E/Q $>$ Peptide E/P $>$ Peptide E/I. It is suggested that the presence of the skip residues dexterously tunes the stability or flexibility of the coiled-coil structure, thus possibly regulating thick filament formation and further gel formation ability of myosin.
\end{abstract}

Keywords: Coiled-coil, myosin, skip residue, synthetic peptide, thermal stability

\section{Stabilitas Termal Peptida Sintetis yang menyerupai Daerah Sekuen yang Mengandung Skip Residue pada Myosin Rod Cumi-Cumi}

\begin{abstract}
Miosin adalah protein utama pada otot rangka (skeletal muscle) yang terdapat pada ikan dan kerangkerangan. Sifat protein ini berhubungan dengan fungsi biologisnya dan sifat fisik dari muscle food. Beberapa residu asam amino, yang disebut juga skip residue berperan dalam ketidakstabilan struktur (hepted repeat) dari miosin rod (daerah koil-koil miosin). Asam amino-asam amino ini bertanggungjawab pada penurunan stabilitas termal. Penelitian ini dilakukan untuk memeriksa peran residu beberapa asam amino pada rod miosin dari cumi-cumi, berdasarkan sifat termodinamika pada peptida sintetik yang didesain mirip sekuen parsial miosin heavy chain otot mantel cumi-cumi (Todarodes pacificus). Lima peptida, yang dimulai dari sekuen posisi $\operatorname{Tr}^{1343}-\mathrm{Ala}^{1372}$ mempunyai skip residue $\mathrm{Glu}^{1357}$ pada pusat (peptida WT), tanpa skip residue (Peptida $\Delta$ ), dengan penggantian skip residue (Glu) dengan Ile, Gln dan Pro (peptida E/I, E/Q, dan E/P) untuk memodifikasi kecenderungan pembentukan heliks yang disintesis. Hasil yang diperoleh menunjukan bahwa stabilitas peptida berurutan Peptide $\Delta>$ Peptide WT $>$ Peptide E/Q $>$ Peptide E/P $>$ Peptide E/I yang diukur dengan spektro circular dichroism. Adanya skip residue mempertajam stabilitas atau fleksibilitas
\end{abstract}


struktur koil, sehingga memungkinkan berperan dalam pembentukan thick filament dan kemudian formasi gel dari miosin.

Kata kunci: koil-koil, myosin, residu, peptida sintetis, stabilitas termal

\section{INTRODUCTION}

Myosin is the principal contractile component in muscles and makes up the major protein in the myofibril (Harrington and Rogers 1984). A number of studies showed that myosins are widely distributed in all eukaryotic organisms, from amoebae and yeasts to higher plants and mammals (Volkmann and Baluska 1999, Sellers 2000, Sokac and Bement 2000). It is established that several myosin isoforms and superfamily are expressed in a single cell, and their recognized numbers increase by the aid of molecular biological approaches (Sokac and Bement 2000, Berg et al. 2001). The structural and functional properties of fish and shellfish myosins have been intensively studied, because of their importance in muscle contraction under various habitat conditions and also in their gel forming ability.

Although force is generated by the interaction of myosin heads with actin filament, force transduction requires the assembly of myosin molecules. In skeletal muscles including from fish and shellfish, myosin assembles into stable thick filaments. Muscle myosins and those found in other tissues belonging to the Class II, called as conventional myosins, resemble each other both structurally and functionally. Only the myosins belonging to Class II are able to form thick filaments via the side-by-side association of the long coiled-coil rods. The conventional myosin molecule is a hexameric protein composed of a pair of heavy chains (approximately $200 \mathrm{kDa}$ ) and two pairs of light chains (approximately $20 \mathrm{kDa}$ ). The $\mathrm{N}$-terminal half of the heavy chain folds into a globular head domain, while the C-terminal halves of the heavy chains wrap around to form an $\alpha$-helical coiled-coil rod domain (Fraser and MacRae 1973, Harrington and Rodgers 1984, Warwick and Spudich 1987). In the head region are located not only the active site for myosin ATPase but also the binding sites for actin and light chain subunits. The rod portion itself is responsible for the assembly of myosin molecules into filaments.
The coiled-coil structure of the myosin rod is formed by the packing of two extended $a$-helices against one another via the characteristic heptad repeats of seven amino acids. The positions of each amino acid in one unit are labeled a through $g$ from the $\mathrm{N}$-terminal side. The a and $\mathrm{d}$ positions are frequently occupied by hydrophobic amino acids to form hydrophobic bonding at the interface of two helices, whereas the e and g positions tend to be occupied with polar amino acids facilitating the salt bridge formation. The other positions, located at the outer surface of the rod, tend to be occupied with hydrophilic amino acids. Therefore, the residues at the a, $\mathrm{d}$, e, and g positions are responsible for the stability of coiledcoil structure. Such positioning is almost complete in tropomyosin which has a coiledcoil structure throughout the entire molecule. In the case of myosin heavy chain, however, the ordered structure of the coiled-coil region is partially destabilized by the presence of several extra residues, known as skip residues (Matulef et al. 1998, Straussman et al. 2005). The rod sequences of some myosins contain the heptad repeats which are interrupted by the presence of four skip residues, resulting in an imperfect coiled-coil structure.

A key sequence required for myosin filament formation consists of 29 residues located close to the $\mathrm{C}$-terminus of the rod. This region, called as assembly competent domain (ACD), has a characteristic charge distribution. The domain was originally found in rabbit skeletal myosin, but later was identified in many conventional myosins (Sohn et al. 1997), and is also found to be present in the squid myosin. On the other hand, the presence of skip residues has been known in mammalian myosins and is considered to be involved in slight local bending of the rod.

In the present study, the role of the skip residues found in molluscan (squid) myosin was investigated by thermodynamic analyses. Namely, five synthetic peptides of 30mer which mimic the partial sequence of squid 
myosin rod were prepared, and the effects of the presence or absence of the skip residue and its replacement by other amino acids on their thermal stability differences were measured, taking the helical contents as a parameter.

\section{MATERIALS AND METHODS Chemicals}

Sodium phosphate, potassium chloride, tricine, 2,2,2-trifluoroethanol (TFA), dithiothreitol (DTT) and acrylamide used in the present study were of reagent grade and purchased from Wako (Osaka, Japan).

\section{Preparation of synthetic peptides}

The complete cDNA sequence of squid Todarodes pacificus myosin heavy chain has been deposited to GenBank with an accession number GU338005 (Figure 1). The sequence $\left(\operatorname{Trp}^{1343}\right.$ to $\left.\mathrm{Ala}^{1372}\right)$ in the rod region (skip residue 2) was targeted in this study, because of its estimated higher helical propensity among the four counterparts in the rod region. Five peptides, namely, Peptide WT (wild type, one skip residue located at the middle of four heptad repeats, NH2-WRSKFES EGAARAD E LYDSKRK LQAELSEA-COOH) and Peptide $\Delta$ (containing four heptad repeats without any skip residue, $\mathrm{NH}_{2}$-WRSKFES EGAARAD LYDSKRK LQAELSEA-COOH) and point-mutated ones with the replacements of the skip residue (Glu) by Ile, Gln and Pro (Peptides E/I, Peptide E/Q, and Peptide E/P, respectively) to modify the helical propensity, were synthesized by Fmoc method as reported previously (Ozawa et al. 2009) (Table 1). All the peptides except Peptide $\Delta$ (29mer), which the skip residue was deleted, were 30 mers. These peptides were provided as approximately $95 \%$ purity.

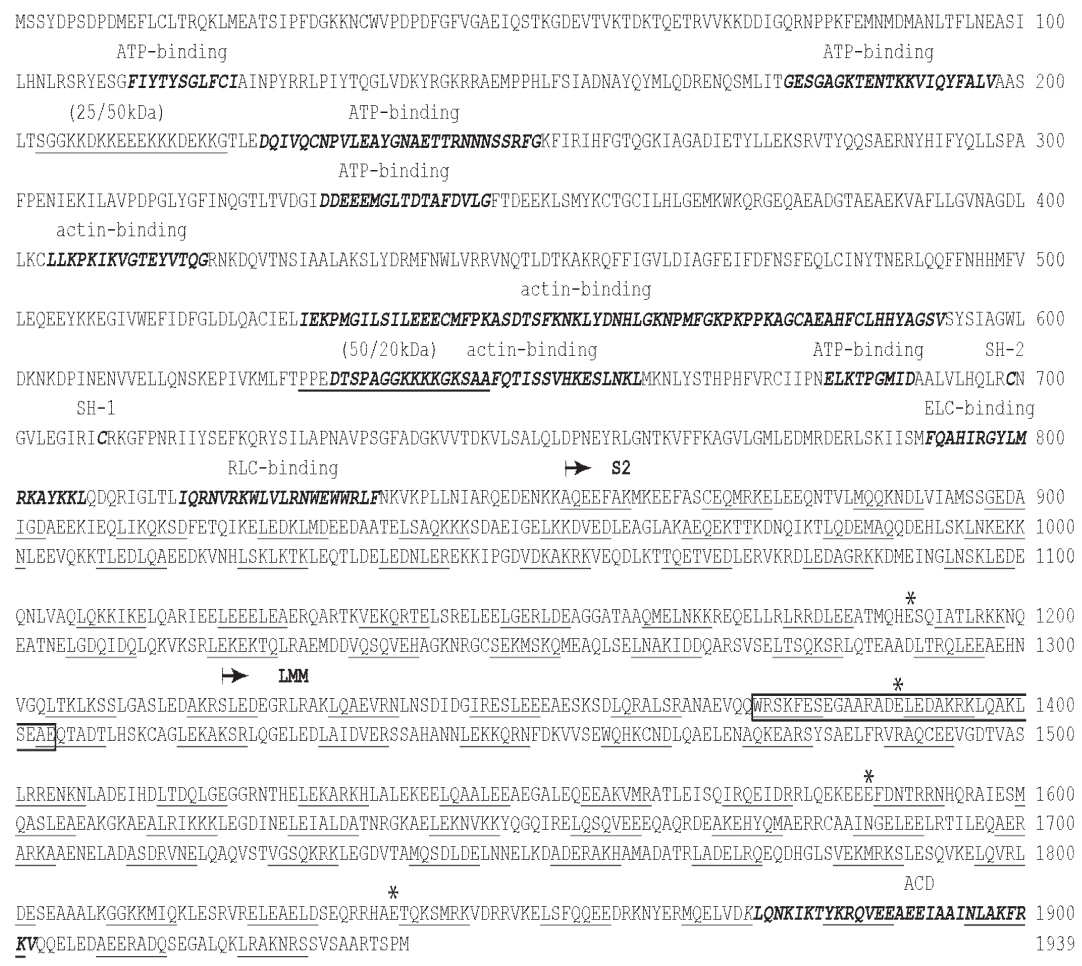

Figure 1 The deduced amino acid sequence of myosin heavy chain from Japanese flying squid Todarodes pacificus mantle muscle. The region focused in the present study is contained in a box. The junction regions between the $25 \mathrm{kDa}, 50 \mathrm{kDa}$ and $20 \mathrm{kDa}$ domains as well as the heptad repeat sequences in the S2 and LMM regions are underlined. The skip residues are indicated with the asterisk. ATP-, actin- and essential light chain (ELC)binding sites, the assembly competent domain (ACD) as well as the reactive cysteine residues (SH-1 and $\mathrm{SH}-2$ ) are shown in italicized bold faced letters. The sequence has been deposited to GenBank with the accession number GU338005. 
Table 1 The sequences of the synthetic peptides used in this study

\begin{tabular}{lcc}
\hline \multicolumn{1}{c}{ Peptides } & \multicolumn{1}{c}{ Sequence } & Size \\
\hline Peptide WT & $\mathrm{NH}_{2}$-WRSKFESEGA ARADELYDSK RKLQAELSEA-COOH & $30 \mathrm{mer}$ \\
Peptide $\Delta$ & $\mathrm{NH}_{2}$-WRSKFESEGA ARAD - LYDSK RKLQAELSEA-COOH & $29 \mathrm{mer}$ \\
Peptide E/I & $\mathrm{NH}_{2}$-WRSKFESEGA ARADILYDSK RKLQAELSEA-COOH & $30 \mathrm{mer}$ \\
Peptide E/Q & $\mathrm{NH}_{2}$-WRSKFESEGA ARADQLYDSK RKLQAELSEA-COOH & $30 \mathrm{mer}$ \\
Peptide E/P & $\mathrm{NH}_{2}$-WRSKFESEGA ARADPLYDSK RKLQAELSEA-COOH & $30 \mathrm{mer}$ \\
\hline
\end{tabular}

\section{Circular dichroism (CD) spectrometry}

These peptides were dissolved in 10 $\mathrm{mM}$ sodium phosphate $(\mathrm{pH} 7.0)$ containing $0.1 \mathrm{M} \mathrm{KCl}, 1 \mathrm{mM}$ DTT, $0.01 \% \mathrm{NaN} 3$ and $40 \%$ TFE, and analyzed by CD spectrometry in the temperature range of $2{ }^{\circ} \mathrm{C}$ to $60{ }^{\circ} \mathrm{C}$. $\mathrm{CD}$ spectra were measured with a J-720 spectropolarimeter (JASCO, Tokyo, Japan), equipped with a jacketed cell of $0.2 \mathrm{~mm}$ optical path length under constant N2 flux. Wavelength and protein concentration for measurement were set in the range of 240 $\mathrm{nm}$ to $190 \mathrm{~nm}$ and $1 \mathrm{mg} / \mathrm{mL}$, respectively. a-Helical content was calculated based on the mean residue ellipticity at $222 \mathrm{~nm}([\theta] 222)$ (Yang et al. 1986, Wallimann et al. 2003).

The thermal stability of the peptides was compared taking the two criteria, namely, the midpoint of melting temperature $(\mathrm{Tm})$ and the enthalpy for folding $(\Delta \mathrm{H})$. The values for $\mathrm{Tm}$ and $\Delta \mathrm{H}$ were calculated based on the assumption that the unfolding can be fit by a helix-coil transition. After normalization to a scale of 0 to 1 , the ellipticity data were modified by the following equations (Yang et al. 1986):

$$
\begin{aligned}
& \alpha=[\theta] 222 /(-36000) \\
& \text { where } \quad \alpha=K /(1+\mathrm{K}) \\
& \text { where } \mathrm{K}=\exp \{(\Delta \mathrm{H} / \mathrm{RT})(\mathrm{T} / \mathrm{Tm})-1\}
\end{aligned}
$$

\section{Tricine polyacrylamide electrophoresis (Tricine PAGE)}

gel

The purity of these peptides was checked by Tricine PAGE (Schägger and Jagow 1987) with a slight modification as reported previously for tropomyosin peptide using $4 \%$ polyacrylamide gel for stacking, $10 \%$ gel for spacing and $16 \%$ gel for separation (Ozawa et al. 2009). Protein concentration was determined by bicinchoninic acid (BCA) method (Smith et al. 1985) using a kit (GE Healthcare Life Sciences Co. Ltd.) and bovine serum albumin as a standard.

\section{Secondary structure prediction}

Secondary structures of the peptides were predicted using the programs from ExPASy Proteomics Tools for secondary structure prediction (AGADIR) (Muñoz and Serrano 1999), under the conditions at $\mathrm{pH} 7.0,278 \mathrm{~K}$, and ionic strength of 0.12 . The 1200 kinds of peptides were analyzed by AGADIR program

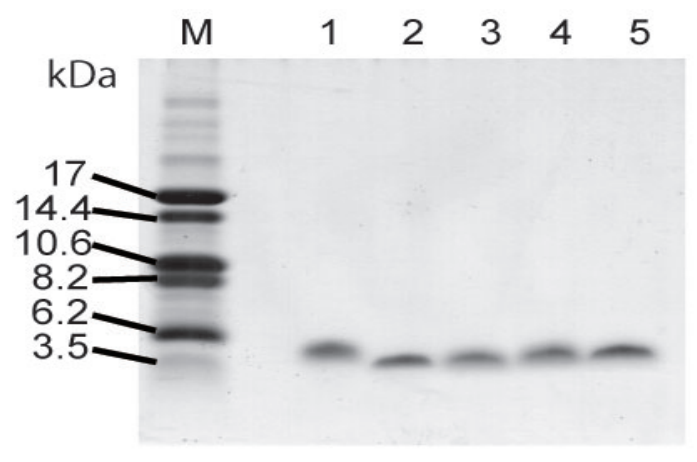

Figure 2 Purity check of the peptides by Tricine PAGE. M, molecular weight markers; 1, Peptide WT; 2, Peptide $\Delta ; 3$, Peptide E/I ; 4, Peptide E/Q; 5, Peptide E/P. One $\mu$ g of each peptide was applied to each lane. The gel of $16 \%$ polyacrylamide was used. 
Table 1 The sequences of the synthetic peptides used in this study

\begin{tabular}{lccccc}
\hline & Peptide E/P & Peptide E/I & Peptide E/Q & Peptide WT & Peptide $\Delta$ \\
\hline$T m\left({ }^{\circ} \mathrm{C}\right)$ & -53.7 & -52.3 & -21.3 & -4 & 1 \\
$\Delta H(\mathrm{~kJ} / \mathrm{mol})$ & -9.6 & -11.7 & -16.2 & -16.8 & -19.2
\end{tabular}

to evaluate the performance of the algorithm, whereas the average deviation of the prediction from experimental values (obtained from CD measurements) was only by $2 \%$ less than the calculated helical content, with a standard deviation of 6 (helical content \%).

\section{RESULTS AND DISCUSSION Purity of the peptides}

The $\mathrm{Rf}$ values of the peptide bands on the gel did not correspond well to the molecular weight calculated from the amino acid sequences (Figure 2): i.e., the expected molecular weights from amino acid sequence were 3,471 for Peptide WT, 3,342 for Peptide $\Delta, 3,456$ for Peptide E/I, 3,471 for Peptide E/Q, and 3,440 for Peptide E/P. All the peptides were found to be of high purity. The results may have possibly come from the differences of amino acid composition for each peptide.

\section{CD spectrometry}

The CD spectrometry of the peptides was carried out in the presence of $40 \%$ TFE, known as an $\alpha$-helix stabilizer (Nelson and Kalenbach 1986, Jaravine et al. 2001, Corrêa and Farah 2007). Table 2 shows the melting temperature $(\mathrm{Tm})$ and the enthalpies $(\Delta \mathrm{H})$ of the five peptides as the thermodynamic parameters of structural stability calculated based on the results of CD spectrometry. In the table, the peptides are aligned in the order of increasing $\mathrm{Tm}$. As far as the calculated $\Delta \mathrm{H}$ values are concerned, Peptide $\Delta$ was considered to be most resistant to thermal decay of helical structure. It was followed by Peptide WT and Peptide E/Q. The values for Peptide E/P and Peptide E/I were clearly lower compared to those of the other peptides. It is thus suggested that Pro, a helix breaker, and Ile, a hydrophobic amino acid, can greatly perturb the local structure.

The hydrophobic bonds in the coiledcoil gave large $\Delta H$ values, which determine the cooperativity of the unfolding. Larger $\Delta \mathrm{H}$ values favor fast unfolding of proteins, while smaller $\Delta \mathrm{H}$ values would slow down the unfolding even at the higher temperatures. Large $\Delta \mathrm{H}$ values may allow the region containing the skip peptide to be flexible. TFE seemed to result in the reduction of cooperativity of $\alpha$-helix unfolding. The $\Delta \mathrm{H}$

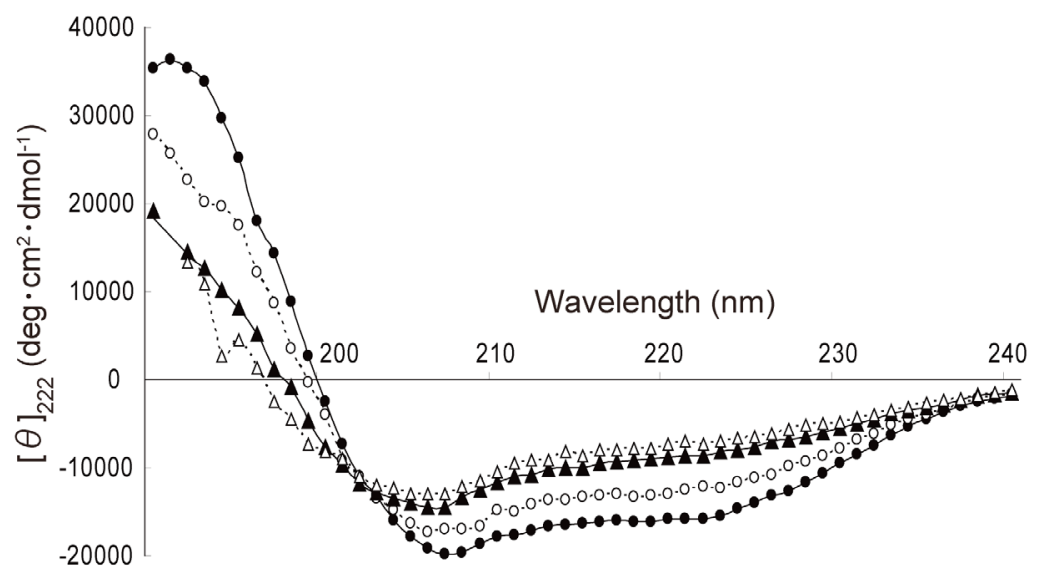

Figure 3 Effects of temperature on the CD spectra of Peptide WT. The measurements were carried out at $5.7^{\circ} \mathrm{C}(\bullet), 21.1^{\circ} \mathrm{C}(\circ), 45.1^{\circ} \mathrm{C}(\boldsymbol{\Delta})$, and $57.8^{\circ} \mathrm{C}(\Delta)$ in $10 \mathrm{mM}$ sodium phosphate (pH 7.0) containing $0.1 \mathrm{M} \mathrm{KCl}, 1 \mathrm{mM}$ DTT, $0.01 \% \mathrm{NaN} 3$, and $40 \%$ TFE. Peptide concentration was $1.0 \mathrm{mg} / \mathrm{mL}$. 


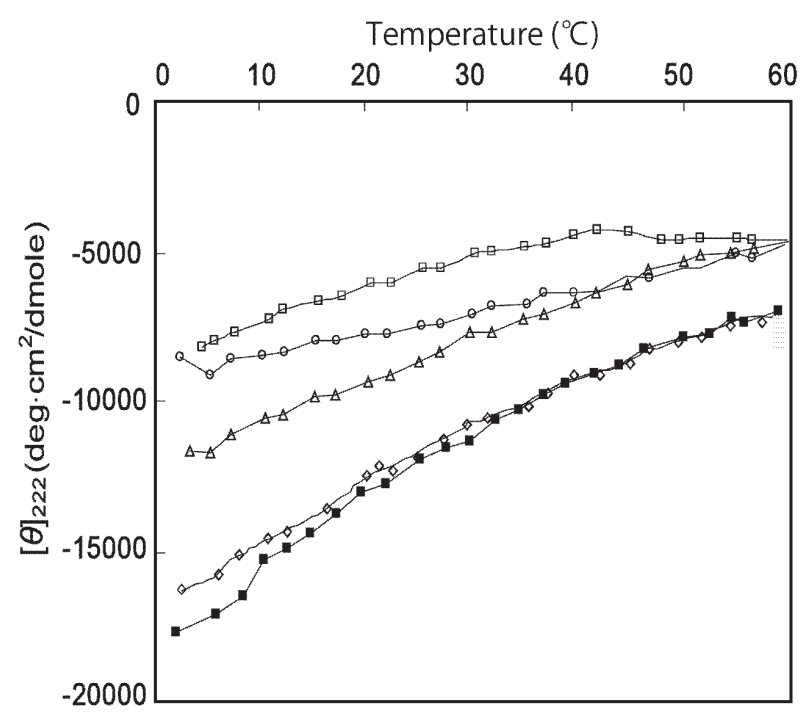

Figure 4 Temperature dependency of the molar ellipticity of the peptides at $222 \mathrm{~nm}$. Peptide WT

$(\square)$, Peptide $\Delta(\diamond)$, Peptide E/I $(\square)$, Peptide E/Q $(\triangle)$ and Peptide E/P $(\bigcirc)$.

and $\mathrm{Tm}$ values showed similar tendency in relation with the $\alpha$-helical contents.

The both ends of a coiled-coil are known to be weakened by the lack of backbone hydrogen bonds, namely, the initial four $\mathrm{NH}$ groups and final four $\mathrm{CO}$ groups lack intrahelical hydrogen-bonding partners (Baldwin and Ros 1999). On the other hand, the stability and unfolding of $a$-helix depend on the ability of forming a coiled-coil structure.

One representative set of spectra of Peptide WT measured at various temperatures are shown in Figure 3. The typical spectra for coiled-coil demonstrated that the peptides formed helical structures. Comparison of the behavior of Peptide WT and Peptide $\Delta$ during thermal treatment from $4{ }^{\circ} \mathrm{C}$ to $60^{\circ} \mathrm{C}$ demonstrated that deletion of the skip residue did not affect the formation of the helical structure at the temperature higher than $32.5{ }^{\circ} \mathrm{C}$, though slight differences were observed at lower temperature (Figure 4). The helix contents of the peptides with the mutations at the skip residue (Peptides E/I, $\mathrm{E} / \mathrm{Q}$, and $\mathrm{E} / \mathrm{P}$ ) were clearly lower compared to that of wild type.

Four skip residues are conserved throughout the conventional myosins, though the ones in the subfragment-2 (S-2) region of myosin are not so well conserved. In the present study, the stability of coiledcoil structure was greatly increased by the substitution of a skip residue Glu by Pro, Gln and Ile. The stability was slightly increased by deleting this skip residue, suggesting that it is involved in the destabilization of myosin rod. It is likely that the residue is rather responsible for local perturbation of coiled-coil formation or bending of the myosin rod. The higher solubility of S- 2 is likely to be due to its shorter length. However, a series of studies using rod fragments produced by proteolysis or by molecular biological methods have shown that deletions from its extreme C-terminus greatly increase its solubility (Nyitray et al. 1983, Sinard et al. 1990, Atkinson and Stewart 1992), whereas deletions of the $\mathrm{N}$-terminus of light meromyosin (LMM) hardly cause changes in solubility. Therefore, the solubility of myosin rod is considered to be governed by a local solubility difference. Incidentally, the detailed structural characteristics of squid heavy meromyosin (HMM) have been reported (O’Neall-Hennessey et al. 2013).

The rod region of myosin heavy chain consists of two parallel $\alpha$-helical polypeptide chains of about 600 residues. Myosin heavy chain polymerizes by side-by-side interaction especially through the assembly competent domain (ACD). In the present study, the five synthetic peptides with the sequence of squid myosin rod (heavy chain) were prepared and their thermal stabilities were compared. The thermostability was measured to investigate 
the effects of amino acid substitution or deficiency of the skip residue. As a result, clear differences in stability of $\alpha$-helix between the peptides were recognized (Figure 4, Table 2), suggesting that the skip residues are important for regulating the stability of the rod region. No attempts have so far been made to the involvement of skip residues in the partial destabilization of the rod region by using synthetic peptides.

The synthetic peptides of 30mer (except Peptide $\Delta$ ) corresponded to approximately four heptad repeats ( $7 \times 4$ amino acids), and therefore, the length of the peptides was considered to be long enough to form a coiled-coil structure. In relation with this, the synthetic peptide (ProProGly) 10 mimicking a collagen fragment existed as a trimer at $11^{\circ} \mathrm{C}$, suggesting these $30 \mathrm{mer}$ peptides formed a triple helix like that of native collagen (Kobayashi et al. 1970). The reason for the designing of these peptides was due to the difficulty in the efficiency of the synthesis of peptides longer than $30 \mathrm{mer}$, especially considering of their yield.

The net scores became negative when the skip residues, which are mostly occupied by a negatively charged residue, are deleted. Actually the skip residues are wedged in the 28 residue repeat zones of the myosin rod. If there was no skip residue at all, the matching between the positive and negative peaks in the corresponding zones in the rod region could be maximized when the stagger is exactly any odd multiple of 14 residues. Therefore, the presence of skip residues causes a frame shift of the heptads which could modify the intermolecular interaction across the corresponding zones of the rod. The presence of four skip residues in the skeletal myosins may be involved in the flexibility of the intermolecular interactions, when compared to those which have three skip residues.

Tropomyosin (TM), a regulatory protein present on actin filaments, possesses a coiledcoil structure along the entire molecule, similar to the myosin rod, but there is no skip residue in TM. Studies on the structure of a-TM from rabbit skeletal muscle fragment (residues 176-273, fused to GCN4, a eukaryotic transcriptional activator protein) revealed that Ala cluster and the broken core regions destabilize the entire molecule (Greenfield et al. 1998). The Ala cluster, where consecutive Ala or Ser residues are clustered at the core, would allow TM to bend at either end of the cluster, so that TM could wrap around the actin filament.

On the other hand, the broken core region is formed around the acidic core residues, as in $\mathrm{Ala}^{134}-\mathrm{Asp}^{137}-\mathrm{Met}^{141}, \mathrm{Tyr}^{214}-\mathrm{Glu}^{218}$ $\mathrm{Tyr}^{221}$ and $\mathrm{Gln}^{263}-\mathrm{Tyr}^{267}$, and is associated with an increase in the spacing between the two $\alpha$-helices forming a coiled-coil, leaving a hole in the middle of the core. The core residues in the hole are exposed to the solvent, resulting in substantial destabilization of the entire molecule. The N-terminal region of this fragment (254-262) shows a typical two-stranded coiled-coil, whereas the C-terminal region (263-284) consists of $\alpha$-helices (22 residues in length) that are separated from each other and are stabilized by crystal packing forces. The pairs of $\mathrm{Gln}^{263}$ and $\mathrm{Tyr}^{267}$ side chains does not display the usual symmetric "knobs-into-holes" packing pattern. Therefore, a skip residue system is quite unique to the myosin rod for tuning its flexibility. TM does not polymerize in a side-by-side manner and thus does not form a thick filament. Though myosin rod and TM have nearly perfect coiled-coil structures, the strategies for filament formation greatly differ from each other.

The molecular basis of myosin assembly is essential in understanding the mechanism of muscle contraction and also the gel formation. All the sequences of the myosins have been reported had similar patterns (Warrick and Spudich 1987), as recognized by the seven-residue repeat characteristic for the coiled-coil structure (Crick 1953). Especially, the periodicity in the charged residues with a repeat of 28 residues seems to be important (Parry 1981, McLachlan and Karn 1982). As a result, the positively and negatively charged zones appear alternatively over the molecule. Such a unique pattern suggests that the electrostatic interactions between the zones provide the energy for myosin assembly, if the molecules were staggered by an odd multiple of 28/2 residues (McLachlan and Karn 1982). 
Actually, the staggers of 14.3 and $43 \mathrm{~nm}$ as can be recognized in the thick filaments of myosin and in the paracrystals of LMM correspond to the staggers caused by the 98 residues (namely $7 \times 28 / 2$ ) and the 294 residues (namely 21 $x$ 28/2), respectively (Huxley 1963). It is thus likely that such charge periodicity is an important factor for the assembly of myosin molecules.

Squid myosin shows unique properties unlike fish muscle myosins (Zhang et al. 2017, Konno 2017). However, the information on molecular mechanism of muscle contraction in coleoid is still fragmentary (Shaffer and Kier 2016). The effects of salt concentration on the behavior of skip residues should be examined to know more about the mechanisms of gel formation and freezing/thawing induced structural changes of squid myosin (GarcíaSánchez et al. 2015). Furthermore, the fact revealed in the present study could help understanding of the behavior of squid myosin throughout processing (Deng et al. 2015, Cortés-Ruiz et al. 2016).

\section{CONCLUSION}

The present study suggests that the skip residues in the squid myosin rod are involved in partial destabilization of this region. It may be closely related to the polymerization of myosin molecule, thus possibly affecting the gel formation ability of this myosin. Further studies are needed to reveal the role of these residues in resistance of this myosin against freezing and thawing.

\section{ACKNOWLEGEMENTS}

The authors would like to thank Dr. Hideo Ozawa for helping the thermodynamic analysis of the peptides.

\section{REFERENCES}

Atkinson SJ and Stewart M. 1992. Molecular interactions in myosin assembly: Role of the 28-residue charge repeat in the rod. Journal of Molecular Biology. 226(1): 7-13.

Baldwin RL, Ros GD. 1999. Is protein folding hierarchic? Local structure and peptide folding. Trends in Biochemcal Sciences 24(1): 26-33.

Berg JS, Powell BC, Cheney RE. 2001. A millennial myosin census. Molecular Biology of the Cell 12(4): 780-794.

Corrêa F, Farah CS. 2007. Different effects of trifluoroethanol and glycerol on the stability of tropomyosin helices and the head-to-tail complex. Biophysical Journal 92(7): 2463-2475.

Cortés-Ruiz JA, Pacheco-Aguilar R, RamírezSuárez JC, Lugo-Sánchez ME, GarcíaOrozco KD, Sotelo-Mundo RR, PeñaRamos A. 2016. Conformational changes in proteins recovered from jumbo squid (Dosidicus gigas) muscle through $\mathrm{pH}$ shift washing treatments. Food Chemistry. 196(1): 769-775.

Crick FHC. 1953. The packing of a-helices: simple coiled-coils. Acta Crystallographica. 6:689-697.

Deng Y, Luo Y, Wang Y, Zhao Y. 2015. Effect of different drying methods on the structure, amino acid composition, protein digestibility and volatile profile of squid fillets. Food Chemistry. 171(15): 168-176.

Fraser RDB, MacRae TP. 1973. Conformation in Fibrous Proteins, Academic Press, New York.

Jaravine VA, Alexandrescu AT, Grzesiek S. 2001. Observation of the closing of individual hydrogen bonds during TFEinduced helix formation in a peptide. Protein Science. 10(5): 943-950.

García-Sánchez G, Sotelo-Romero CR, Pacheco-Aguilar R, Ramírez-Suárez JC, Sotelo-Mundo R, Scheuren-Acevedo MS, García-Sifuentes CO, MartínezPorchas M. 2015. Effect of freezing on protein denaturation and gelling capacity of jumbo squid (Dosidicus gigas) mantle muscle. $L W T$ - Food Science and Technology. 60(2): 737-742.

Greenfield NJ, Montelione GT, Farid RS, Hitchcock-DeGregori SE. 1998. The structure of the N-terminus of striated muscle a-tropomyosin in a chimeric peptide: nuclear magnetic resonance structure and circular dichroism studies. Biochemistry. 37(21): 7834-7843.

Harrington WF, Rogers ME. 1984. Myosin. Annual Review of Biochemistry. 53: 35-73. Huxley HE. 1963. Electron microscope studies 
on the structure of natural and synthetic protein filaments from striated muscle. Journal of Molecular Biology. 7(3): 281308.

Kobayashi Y, Sakai R, Kakiuchi K, Isemura T. 1970. Physicochemical analysis of (Pro-Pro-Gly)n with defined molecular weight-temperature dependence of molecular weight in aqueous solution. Biopolymers. 9(4): 415-425.

Konno K. 2017. Myosin denaturation study for the quality evaluation of fish musclebased products. Food Science and Technology Research. 23(1): 9-21.

Matulef K, Sirokman K, Perreault-Micale CL and Szent-Gyorgyi AG. 1998. Aminoacid sequence of squid myosin heavy chain. Journal of Muscle Research and Cell Motility. 19(6): 705-712.

McLachlan AD and Karn K. 1982. Periodic charge distributions in the myosin rod amino acid sequence match cross-bridge spacings in muscle. Nature. 299: 226-231.

Muñoz V, Serrano L. 1999. Development of the multiple sequence approximation within the AGADIR model of $\alpha$-helix formation: comparison with Zimm-Bragg and Lifson-Roig formalisms. Biopolymers. 41(5): 495-509.

Nelson JW, Kallenbach NR. 1986. Stabilization of the ribonuclease S-peptide $\alpha$-helix by trifluoroethanol. Proteins. 1(3): 211-217.

Nyitray L, Mocz G, Szilagyi L, Balint M, Lu RC, Wong A, Gergely J. 1983. The proteolytic substructure of light meromyosin. Localization of a region responsible for the low ionic strength insolubility of myosin. Journal of Biological Chemistry. 258(21): 13213-13220.

O’Neall-Hennessey E, Reshetnikova L, Senthil Kumar VS, Robinson H, SzentGyörgyi AG, Cohen C. 2013. Purification, crystallization and preliminary X-ray crystallographic analysis of squid heavy meromyosin. Acta Cryst. F69, 248-252.

Ozawa H, Watabe S, Ochiai Y. 2009. Thermal stability of the synthetic peptides with the sequence of fish fast skeletal muscle tropomyosin. Fisheries Science. 75(4): 1029-1037.

Parry DAD. 1981. Structure of rabbit skeletal myosin: Analysis of the amino acid sequences of two fragments from the rod region. Journal of Molecular Biology. 153(2):459-464.

Schägger H, Jagow VJ. 1987. Tricine-sodium dodecyl sulfate-polyacrylamide gel electrophoresis for the separation of proteins in the range from 1 to $100 \mathrm{kDa}$. Analytical Biochemistry. 166(2): 368-379.

Sellers JR. 2000. Myosins: a diverse superfamily. Biochimica Biophysica Acta - Molecular Cell Research. 1496(1): 3-22.

Shaffer JF, Kier WM. 2016. Tuning of shortening speed in coleoid cephalopod muscle: no evidence for tissue-specific muscle myosin heavy chain isoforms. Invertebrate Biology. 135(1): 3-12.

Sinard JH, Rimm DL, Pollard TD. 1990. Identification of functional regions on the tail of Acanthamoeba myosin-II using recombinant fusion proteins. II. Assembly properties of tails with $\mathrm{NH}_{2}$ - and $\mathrm{COOH}-$ terminal deletions. The Journal of Cell Biology 111(6): 2417-2426.

Sirokman K, Szent-Györgyi AG, Matulef K, Perreault-Micale CL. 1998. Amino-acid sequence of squid myosin heavy chain. Journal of Muscle Research and Cell Motility. 19(6): 705-712.

Smith PK, Krohn RI, Hermanson GT, Mallia AK, Gartner FH, Provenzano MD, Fujimoto EK, Goeke NM, Olson BJ, Klenk DC. 1985. Measurement of protein using bicinchoninic acid. Analytical Biochemistry. 150(1): 76-85.

Sohn RL, Vikstrom KL, Strauss M, Cohen C, Szent-Gyorgyi AG, Leinwand LA. 1997. A 29 residue region of the sarcomeric myosin rod is necessary for filament formation. Journal of Molecular Biology. 266(2): 317-330.

Sokac AM, Bement WM. 2000. Regulation and expression of metazoan unconventional myosins. International Review of Cytology. 200: 197-304.

Straussman R, Squire JM, Ben-Ya'acov A, Ravid S. 2005. Skip residues and charge interactions in myosin II coiled-coils: implications for molecular packing. Journal of Molecular Biology. 353(3): 613628. 
Volkmann D, Baluska F. 1999. Actin cytoskeleton in plants: from transport networks to signaling networks. Microscopy Research and Technology. 47(2):135-154.

Wallimann P, Kennedy RJ, Miller JS, Shalongo W, Kemp DS. 2003. Dual wavelength parametric test of two-state models for circular dichroism spectra of helical polypeptides: anomalous dichroic properties of alanine-rich peptides. Journal of The American Chemical Society. 125(5): 1203-1220.
Warrick HM, Spudich JA. 1987. Myosin structure and function in cell motility. Annual Review of Cell Biology. 3: 379-421

Yang JT, Wu CC, Martinez HM. 1986. Calculation of protein conformation from circular dichroism. Methods in Enzymology. 130: 208-268.

Zhang R, Zhou R, Pan W, Lin W, Zhang X, Li M, Li J, Niu F, Li A. 2017. Salting-in effect on muscle protein extracted from giant squid (Dosidicus gigas). Food Chemistry. 215(15): 256-262. 